\title{
Optimum Population Size of Indigenous P-solubilizing Bacteria to Correct PAvailability in Acid Soils
}

\author{
Sabaruddin ${ }^{1,2, *}$, Marsi $^{1,2}$ and Desti ${ }^{1}$ \\ ${ }^{1}$ Department of Soil Science, Faculty of Agriculture, Sriwijaya University, South Sumatra, Indonesia. \\ ${ }^{2}$ Department of Crop Science, Graduate Program, Sriwijaya University, Jl. Padang Selasa No. 524, \\ Bukit Besar, Palembang 30139, South Sumatra, Indonesia. \\ *Corresponding authoremail: sabar@mail.pps.unsri.ac.id and sabar63@yahoo.com
}

Received 17 February 2010 / accepted 19 October 2010

\begin{abstract}
Indonesian acid soils were used to determine an optimum population size of indigenous P-solubilizing bacteria (PSB) for solubilizating fixed P. The experiment consisted of two sub-experiments. Sub-experiment I was to isolate the indigenous PSB from Ultisols, Fresh-water lowland Inceptisols, and tidal-swamp Inceptisols. Subexpriment II was to study the capacity of the isolated PSB to correct P availability in acid soils by inoculating the isolated PSB into the tested soils at $0,10^{5}, 10^{10}$, and $10^{15}$ cells. The population of the indigenous PSB in the tested soils increased as a result of the inoculation. Both Al-P and Fe-P content in the three tested soils decreased as compared with the initial content. The increases of available $\mathrm{P}$ were significantly correlated with the decreases both in Al-P $\left(r^{2}=0.68\right.$ for the Ultisols; $r^{2}=0.51$ for the fresh-water Inceptisols; and $r^{2}=0.35$ for the tidal-swamp Inceptisols $)$ and in Fe-P $\left(r^{2}=0.91\right.$ for the Ultisols; $r^{2}=0.45$ for the fresh-water lowland Inceptisols; and $r^{2}=0.78$ for the tidal-swamp Inceptisols). The increases of available $\mathrm{P}$ were significantly correlated with the increases of the population of the PSB $\left(r^{2}=0.60\right.$ for the Ultisols; $r^{2}=0.55$ for the fresh-water lowland Inceptisols; and $r^{2}=0.69$ for the tidal-swamp Inceptisols). The available P in the three tested soils sharply increased if the population size of the PSB was about $1 \times 10^{9} \mathrm{cfu} \mathrm{g}^{-1}$ of soil.
\end{abstract}

Keywords: Al-P, Fe-P, fresh-water lowland, isolated, Pikovskaya medium, tidal swamp

\section{INTRODUCTION}

The form of $\mathrm{P}$ most readily accessed by plants is $\mathrm{Pi}$ (in-organic $\mathrm{P}$ ), the concentration of which rarely exceeds $10 \mu \mathrm{m}$ in soil solutions (Bieleski 1973; Paul and Clark 1989). Therefore, in many agricultural systems, application of $\mathrm{P}$ fertilizers to the soil is necessary to ensure plant growth and productivity. However, more than $80 \%$ of the added $\mathrm{P}$ becomes immobile in acid soils and unavailable for plant uptake because of the strong fixation into unavailable complexes (Rajan and Watkinson 1976; Mehadi and Taylor 1988; Holford 1997; Rodríguez and Fraga 1999). Various soil properties have been reported to be closely related to the $\mathrm{P}$ retention capacity of soils (Bertrand et al. 2003; Daly et al. 2001; Leclerc et al. 2001). Furthermore Burt et al. (2002), Borling et al. (2001) and Ige et al. (2003) suggested the combination of $\mathrm{Fe}_{\mathrm{OX}}$ and $\mathrm{Al}_{\mathrm{OX}}$ for the prediction of soil $\mathrm{P}$ sorption capacity in noncalcareous soils.

J Trop Soils, Vol. 16, No. 1, 2011: 55-62 ISSN 0852-257X
Numerous microorganisms, especially those associated with roots, have the ability to increase plant growth and productivity (Glick 1995; Gyaneshwar et al. 1998). In few cases, this effect has been suggested to involve solubilization of otherwise unavailable mineral nutrients. This group of bacteria has been termed 'plant growth promoting rhizobacteria' or PGPR. Among of this group is phosphate-solubilizing bacteria (PSB), which is already used as commercial biofertilizers for agricultural improvement (Suba Rao 1993; Rodríguez and Fraga 1999).

Although PSB occur in soil, usually their numbers are not high enough to compete with other bacteria commonly established in the rhizosphere. Therefore, for agronomic purposes, inoculation at a much higher number than those normally found in soil is necessary to take advantage of their beneficial properties for plant yield enhancement (Igual et al. 2001) because the efficiency of biological solubilization of insoluble $\mathrm{P}$ is also affected by environmental factors (Taiwo and Ogundiya 2008).

Acid Ultisols of South Sumatra has been reported to have a population size of the indigenous 
PSB ranging from 0.1 to $0.2 \times 10^{7}$ colony forming unit (cfu) per gram of soil (Sabaruddin 2004). Such population size was not capable of correcting $\mathrm{P}$ availability in the investigated soils, due to low population size and low potential $P$ reserve in the soils. Therefore, the inoculation of PSB into the soils may alleviate this problem. Current paper reported results of a study on the attempt to determine the optimum population size of the indigenous PSB for optimum solubilization of $\mathrm{P}$ in acid soils.

\section{MATERIALS AND METHODS}

\section{Soil Sampling}

Soils were collected from three field sites to represent three different acid soils widely found in South Sumatra, Indonesia. The first field site, Sembawa Village, Banyuasin District, South Sumatra Province, was represented by Ultisols, while the other two were represented by Inceptisols. The Inceptisols was taken from two lowland areas, fresh-water lowland and tidal swamp. The fresh-water lowland Inceptisol was collected from Agro Techno Park, Gelumbang, Muara Enim District, South Sumatra Province, and the tidal-lowland Inceptisol sample was collected from Telang II Village, Banyuasin District, South Sumatra Province.

Three disturbed soil samples were collected from the depth of 0 to $30 \mathrm{~cm}$ of each field site. To avoid contamination, sampling tools were sterilized using alcohol $(70 \% \mathrm{v} / \mathrm{v})$ prior to sampling. The soil samples were kept in a cooler box and transferred into a refrigerator unless directly characterized. The Ultisols characterized by high acidity ( $\mathrm{pH} 4.60$ ), very low content of available $\mathrm{P}$ (2.95 $\mu \mathrm{g} \mathrm{g}^{-1}$ of soil), and high and very high content of Al-P (71.25 $\mu \mathrm{g} \mathrm{g}^{-1}$ of soil) and Fe-P (306.17 $\mu \mathrm{g}$ $\mathrm{g}^{-1}$ of soil), consecutively. The fresh-water lowland soil was characterized by high acidity ( $\mathrm{pH} 4.85$ ), moderate content of available $\mathrm{P}\left(10.15 \mu \mathrm{g} \mathrm{g}^{-1}\right.$ of soil) and low content of Al-P (12.75 $\mu \mathrm{g} \mathrm{g}^{-1}$ of soil) but very high content of Fe-P (262.46 $\mu \mathrm{g} \mathrm{g}^{-1}$ of soil). The tidal-swamp soil was characterized by high acidity ( $\mathrm{pH} 4.69$ ), high content of available $\mathrm{P}$ (18.41 $\mu \mathrm{g} \mathrm{g}^{-1}$ of soil) but moderate content of Al-P (41.25 $\mu \mathrm{g} \mathrm{g}^{-1}$ of soil) and very high content of Fe-P (378.49 $\mu \mathrm{g} \mathrm{g}^{-1}$ of soil).

\section{Experimental Outline}

Current experiment consisted of two subexperiments. Sub-experiment I was meant to obtain indigenous PSB isolates from each soil. Subexperiment II was to investigate the ability of PSB isolated in the Sub-experiment I in correcting $\mathrm{P}$ availability of soils. Both Sub-experiment I and Sub-experiment II were conducted at the Laboratory of Soil Chemistry, Biology and Fertility of Soil Science Department, Faculty of Agriculture, Sriwijaya University, Indralaya, South Sumatra.

PSB were isolated using modified Pikovskaya's agar medium. Instead of using $\mathrm{Ca}_{3}\left(\mathrm{PO}_{4}\right)_{2}$, current experiment used Al-P as a source of $\mathrm{P}$ in the growth medium to get PSB isolates, which were well adapted to high solubility of $\mathrm{Al}$ in the tested soils. In addition, Bromophenol Blue 0.4\% (Gupta et al. 1994) was also added as a dying agent to enhance PSB colony identification.

Prior to isolation, soils were sieved $(1.00 \mathrm{~mm}$ aperture) to separate debris. The soils ( $10 \mathrm{~g})$ were transferred into a $250-\mathrm{mL}$ erlenmeyer containing $90 \mathrm{~mL}$ of sterilized physiological solution $(8.5 \mathrm{~g}$ $\mathrm{NaCl} \mathrm{L}{ }^{-1} \mathrm{H}_{2} \mathrm{O}$ ) to obtain $10^{-1}$-soil suspension. The suspension was shaken reciprocally for 20 minutes, and $1 \mathrm{~mL}$ of the suspension was pipetted into test tubes containing $9 \mathrm{~mL}$ of sterilized physiological solution to obtain $10^{-2}$-soil suspension. These steps were repeated up to $10^{-7}$-dilution level.

PSB were isolated by transferring $1 \mathrm{~mL}$ of soil suspension into sterilized petri dishes containing sterilized Pikovkaya's medium $(10 \mathrm{~mL}$ per petridish). The petridish was then swirled to homogenize the soil suspension and the growth medium, and incubated in an incubator for 4 days at $30^{\circ} \mathrm{C} \pm 1^{\circ} \mathrm{C}$. PSB colony was characterized by clear zones on the medium. Only petridishes resulting 30 to 300 colonies were included in the colony counting.

Sub-experiment II consisted of 2 stages. The first stage was to propagate sufficient number of PSB isolates for the subsequent $\mathrm{P}$ availability experiment. Propagation was carried out in liquid Pikovskaya's medium. The inoculation rate tested in the Sub-experiment II were 0 (no inoculation), $10^{5}, 10^{10}$, and $10^{15}$ cells of PSB ml ${ }^{-1}$ of inoculant.

Correction on $\mathrm{P}$ availability by PSB was investigated by inoculation and incubation methods. Prior to inoculation, the soils were sieved $(1.00 \mathrm{~mm}$ aperture) to separate debris. The three tested soils were saturated with $P$ by adding $0.65 \mathrm{~g}, 0.37 \mathrm{~g}$, and $0.43 \mathrm{~g} \mathrm{SP}-36$ into the Ultisols, the two types of Inceptisols, consecutively, and then equilibrated for one week. Soil water content was maintained at field capacity during the equilibrium period (Marsi and Sabaruddin 2006). The P-saturated soils (200 g) were transferred into plastic containers. The soils were then inoculated with 0 (no inoculation), $10^{5}$, $10^{10}$, and $10^{15}$ cells $\mathrm{ml}^{-1}$ of PSB inoculant. Two milliliter of PSB inoculant was pipetted into the 
soils; and two milliliter of regular water was used for the uninoculated soils. The soils were incubated at $30^{\circ} \mathrm{C} \pm 1^{\circ} \mathrm{C}$ for 60 days.

\section{Measurement}

Measurements were made on the population density of PSB at 0 (prior to inoculation), 7, 15, 30, and 60 days after incubation, and available $P$ and fixed $\mathrm{P}$ (Al-P and Fe-P) at 7, 15, 30, and 60 days after incubation.

\section{Statistical Analysis}

Population density of PSB was averaged over 5-petridish readings. ANOVA was performed to test the effects of treatments on PSB variables using General Linear model (GLM) of Costat Version 2.0. Relationships among variables were analysed using regression and correlation analysis.

\section{RESULTS AND DISCUSION}

\section{PSB Population}

Table 1 presents the population of PSB during the experiment. Data on 0d was the population of PSB at the start of the experiment (immediately prior to inoculation). In relation to the dynamics of PSB's population in Table 1, there are two important findings of current experiment. First, inoculation increased the population of PSB in all tested soils. Second, the population of PSB in all tested soils fluctuated over time.

One of basic and important indicators to estimate the success of inoculating microbes into the soils is the population density of the introduced microbes some times after the inoculation (van Veen et al. 1997). Current experiment showed that increases in inoculant density were followed by constant increases in population density of PSB in the three tested soils (Tabel 1). Similar results were also reported by Reyes et al. (2002) who observed a significant increase of total rhizospheric bacterial community and PSB population in soil as a result of introducing nonindigenous strain of PSB. Capability of the introduced bacteria of responding external stimulant, such as soil $\mathrm{pH}$, nutrient availability, soil moisture, is an important characteristic. Such capability reflects adaptability of the bacteria to their new environment. The increasing population density of PSB in the soils of current experiment demonstrated positive response of the introduced PSB to the growing factors in the soils, such as sufficient availability of Al- and Fe-P in soils and favorable soil moisture and temperature during the experiment. In addition, the increases in population density of PSB observed in current study as well in previous study by Reyes et al. (2002) confirmed that the introduced PSB successfully colonized the soil and interacted with the indigenous PSB.

The population density of PSB in the soils was fluctuating over time (Table 1). The declining population density of PSB in the uninoculated soils occurred because the soil-born PSB could not survive the growth condition (nutrient deficiency and unfavorable soil micro conditions), and this constraint is known as a 'microbiostatic' phenomenon (Ho and Ko 1985). Because the

Table 1. Dynamics of PSB population in tested soils

\begin{tabular}{|c|c|c|c|c|c|c|}
\hline \multirow{3}{*}{ Soils } & \multirow{2}{*}{ Inoculant density } & \multicolumn{5}{|c|}{ PSB population at } \\
\hline & & $0 \mathrm{~d}$ & $7 \mathrm{~d}$ & $15 \mathrm{~d}$ & $30 \mathrm{~d}$ & $60 \mathrm{~d}$ \\
\hline & inoculant $-\mathrm{ml}^{-1}$ of & \multicolumn{5}{|c|}{ 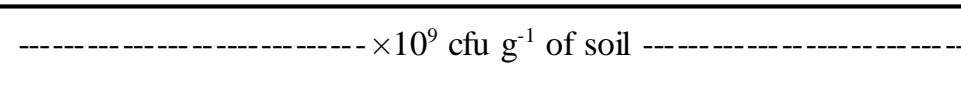 } \\
\hline \multirow[t]{4}{*}{ Ultiso ls } & 0 & 0.0000057 & 0.00005 & 0.00049 & 0.000047 & 0.00044 \\
\hline & $0.12 \times 10^{5}$ & 0.0000057 & 0.055 & 5.46 & 0.0054 & 0.0068 \\
\hline & $0.12 \times 10^{10}$ & 0.0000057 & 4.73 & 6.69 & 0.05 & 0.06 \\
\hline & $0.12 \times 10^{15}$ & 0.0000057 & 5.37 & 7.71 & 0.44 & 0.53 \\
\hline Freshwater- & 0 & 0.000045 & 0.00017 & 0.0002 & 0.00018 & 0.00021 \\
\hline lowland & $0.72 \times 10^{5}$ & 0.000045 & 0.12 & 0.20 & 0.17 & 0.21 \\
\hline \multirow[t]{2}{*}{ Inceptisols } & $0.72 \times 10^{10}$ & 0.000045 & 14.75 & 17.50 & 16.04 & 20.00 \\
\hline & $0.72 \times 10^{15}$ & 0.000045 & 17.81 & 20.06 & 19.98 & 21.45 \\
\hline Tidal swamp & 0 & 0.000028 & 0.00027 & 0.0003 & 0.00024 & 0.0003 \\
\hline \multirow[t]{3}{*}{ Inceptisols } & $2.29 \times 10^{5}$ & 0.000028 & 0.26 & 0.25 & 0.21 & 0.26 \\
\hline & $2.29 \times 10^{10}$ & 0.000028 & 25.22 & 23.83 & 17.86 & 21.33 \\
\hline & $2.29 \times 10^{15}$ & 0.000028 & 26.92 & 27.92 & 21.22 & 29.58 \\
\hline
\end{tabular}


availability of nutrients, mainly $\mathrm{P}$, in the soils used in current study was corrected prior to the inoculation of PSB, the decline in the population of PSB in the uninoculated soils was caused by the failure of the soil-born PSB to adapt to the controlled growth condition. In addition, it was also an evidence for an ecological selection process occurring in the soils. Hence, it is believed that the counted PSB in the uninoculated soils in current study belonged to PSB, which managed to overcome the 'microbiostatic' constraints.

The population of PSB in the inoculated soils showed similar pattern of dynamics. The population density increased up to 15 days after incubation, and declined subsequently. The population decline occurred through several mechanisms (Elliot et al. 1980; van Elsas et al. 1991). Soil characteristics, such as texture, $\mathrm{pH}$, temperature, and moisture content, exert direct effects on microbial population in soils because these factors determine cell performance (Elliot et al. 1980; van Elsas et al. 1991). Because these factors were kept uniform during the experiment, the decline in the PSB's population observed in current study was not driven by factors as described by Elliot et al. (1980) and van Elsas et al. (1991). In stead, it was caused by indirect effects of the abiotic factors, stimulating competitions between PSB and any other microbes in the soils as explained by Paul and Clark (1989) and Berry and Hagedorn (1991).

In addition to the abiotic factors, biotic factors are also contributing factors to the declining population of PSB in current study. Protozoa living in the soils can function as a regulator of the survival of introduced bacteria because they graze on the inoculated bacteria (Danso and Alexander 1975; Habte and Alexander 1975; Heijnen et al. 1988; Wright et al. 1993; Wright et al. 1995). The decline in the population of the introduced bacteria was significantly correlated with the increases in protozoa activity in the soils (Heijnen et al. 1988; Wright et al. 1995). Once the soils were sterilized prior to inoculation, the decline was not observed (Heijnen et al. 1988).

Additionally, population decline was also driven by competion over substrat and space between the indigenous microbes in the soils and the inoculated PSB. As shown in the previous experiment, strelized soils were inoculated with consortium of bacteria, protozoa, and combination of bacteria and protozoa. The soils receiving those treatments were then inoculated with Rhizobium leguminosarum bv. trifolii. The results showed that population of the rhizobia were not affected by single inoculation, either bacteria alone or protozoa alone. Significant decline in the population of the introduced rhizobia was observed only in soils receiving dual inoculations of bacteria and protozoa (Postma et al. 1990).

Current experiment also found significantly different population density of PSB among the three tested soils (Table 1). The highest population density of PSB during the experiment was consistently observed in the tidal-swamp Inceptisols. In a field experiment using genetically modified bacteria, it was showed that under the same climate condition, the introduced Pseudomonas had better survival rate in finetextured soils (clay) as compared with those in coarse-textured soils (van Elsas et al. 1986). It happened because clay could physically protect the introduced Pseudomonas from predation by the protozoa (Marshall 1975). However, such argument failed to describe why the population density of PSB in the tidal-swamp soil of current study was higher than that in the other two soils in spite of the fact that the tidal-swamp Inceptisols had the lowest content of clay fraction (13.8\%), while the Ultisols and the fresh-water lowland Inceptisols had 24.4\% and $35.2 \%$, consecutively.

Chemically, the three tested soils were acidic with $\mathrm{pH}$ of 4.60 in Ultisols, 4.85 in fresh-water lowland soil, and 4.69 in tidal-swamp soil. Hence, soil $\mathrm{pH}$ could not either be regarded as an important driving force that caused the differences in population density of PSB in the three soils. In seems that, higher amount of fixed $\mathrm{P}$ ( $\mathrm{Al}-$ and $\mathrm{Fe}-$ $\mathrm{P})$ and organic matter in the tidal-swamp soil than those in the other two soils appeared to be an important factor for the survival and growth of PSB.

\section{Population Density of PSB and Available P}

Amount of available $\mathrm{P}$ in the three soils shows steady increases with time (Figure 1). The increases were exceptionally already evident at $7 d$ of incubation and highest in the Ultiosols. To further investigate the main source of $\mathrm{P}$ in current experiment, both $\mathrm{Al}$ - and $\mathrm{Fe}-\mathrm{P}$ complexes were also measured, as presented in Figure 2. The increases in available $\mathrm{P}$ in the three tested soils were significantly correlated with the decreases in both $\mathrm{Al}-$ and Fe-P (Figure 3) and with the increases in PSB population (Figure 4).

Soil microbes have been recognized as an important component linking soil system with plant, mainly through their roles in biogechemical cycle of soil nutrients (Jeffries and Barea 1994; Oberson et al. 1993). About $20 \%$ of soil microbes are contributing to the solubilization of unavailable inorganic $\mathrm{P}$, such as $\mathrm{Al}-$ and $\mathrm{Fe}-\mathrm{P}$, and known as 


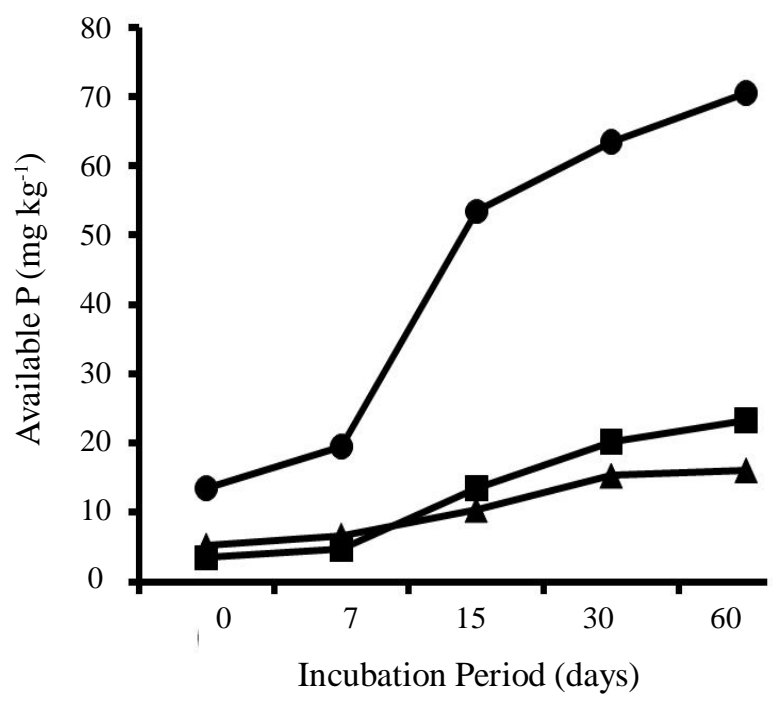

Figure 1. Changing in available $\mathrm{P}$ in Ultisols (๑), fresh-water lowland Inceptisols ( $\mathbf{\square})$, and tidal-swamp Inceptisols $(\mathbf{A})$

PSB (Goldstein 1986; Cerezine et al. 1988; Illmer et al. 1995; Gyaneshwar et al. 1998).

Two main sources of available $\mathrm{P}$ in the current study (Figure 1) include decomposition of organic $P$ and solubilization of unavailable inorganic P. Decomposition of organic P was not measured in the current experiment. However, the decreases in the Al-P and Fe-P (Figure 2) indicate that these two pools of the unavailable $P$ contributed to the increases of the available $P$ in soils. The decline of Fe-P in the three tested soils showed a similar pattern (Figure 2a), while Al-P in the tidal-swamp Inceptisols showed a sharp decline during the first week of incubation and showed a similar patter for the rest of incubation period of the three soils (Figure $2 b$ ). This argument was supported by a significant relationship between the decreases of the fixed $P$ and the increases of the available $\mathrm{P}$ in the three tested soils, as shown by Figure 3 .

Figure 4 depicted the relationship between the population density of PSB and the available $\mathrm{P}$ in the three tested soils. Figure 4 clearly shows that the increases of the available were significantly correlated with the increases of the PSB population. About $60 \%, 55 \%$, and $69 \%$ of the increases in the available $\mathrm{P}$ in the Ultiosols, fresh-water lowland Inceptisiols, and tidal-swamp Inceptisols, were mediated by the activity of PSB. In a previous experiment it was shown that inoculating calcareous soils with $10^{9}$ cells of PSB g-1 of soils increased the available $P$ as much as $60 \mu \mathrm{g} \mathrm{g}^{-1}$ of soil as compared with the uninoculated control (Egamberdiyeva et al. 2004). However, acid soils used in the current
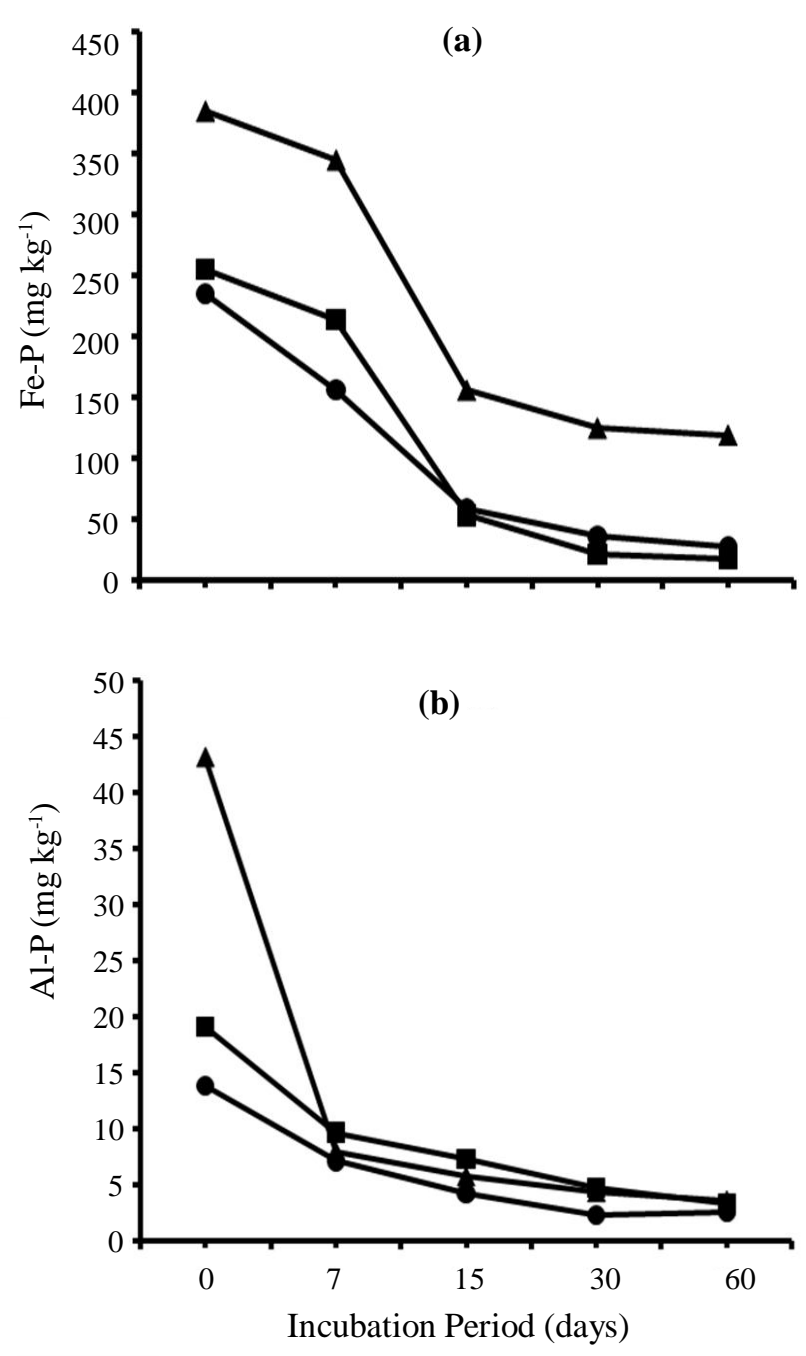

Figure 2. Changing in fixed $\mathrm{P}$ in Ultiosols ( $\mathbf{\bullet}$ ), fresh-water lowland Inceptisols ( $\mathbf{\square})$, and tidal swamp Inceptisols ( $\mathbf{\Delta})$.

study showed different pattern of response. The highest available $P$ contents were $72.6 \mu \mathrm{g} \mathrm{g}^{-1}$ in the Ultisols, $29.40 \mu \mathrm{g} \mathrm{g}^{-1}$ in the fresh-water Inceptisols, and $17.55 \mu \mathrm{g} \mathrm{g}^{-1}$ in the tidal-lowland Inceptisols. At the same time, the population density of PSB was $7.71 \times 10^{9}$ cells g$^{-1}$ in the Ultisols, $19.98 \times 10^{9}$ cells $\mathrm{g}^{-1}$ in the fresh-water Inceptisols, and $21.22 \times$ $10^{9}$ cells $\mathrm{g}^{-1}$ in the tidal-swamp Inceptisols, consecutively. Such differences were likely due to the inherent differences of characteristics among the three tested soils, which were were important in determining whether $P$ released through bilogical dissolution by the PSB would be adsorbed by soil components or readily available for plant uptake (Bertrand et al. 2003; Daly et al. 2001; Leclerc et al. 2001). Zhang et al. (2005) further explained that the significant correlation observed between $\mathrm{P}$ sorption capacity and clay content was due to the significant indirect influences of $\mathrm{Al}_{\mathrm{OX}}$ and $\mathrm{Fe}_{\mathrm{OX}}$. 

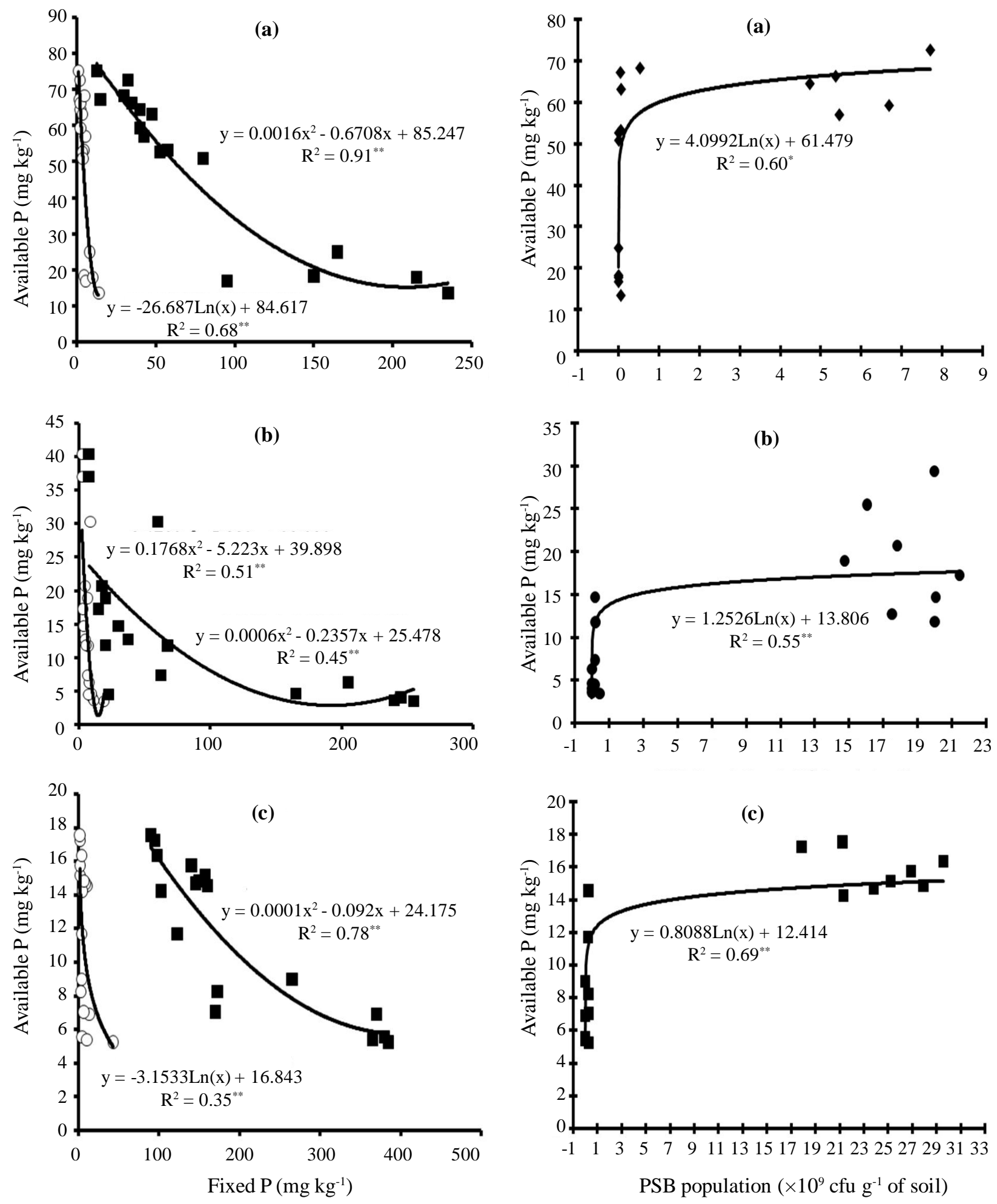

Figure 3. Relationship between fixed $\mathrm{P}$ and available $\mathrm{P}$ in Ultisols (a), fresh-water lowland Inceptisols (b), and tidal-swamp Inceptisols (c). $\square=\mathrm{Al}-\mathrm{P}, \mathrm{O}=\mathrm{Fe}-\mathrm{P}$.

Figure 4 also shows that the threshold population size of PSB to significantly increase the available $P$ in the acid soils of Indonesia must be at least $0.055 \times 10^{9} \mathrm{cfu} \mathrm{g}^{-1}$ of soil in the Ultisols, 0.17 $\times 10^{9} \mathrm{cfu} \mathrm{g}^{-1}$ of soil in the fresh-water Inceptisols, and $0.21 \times 10^{9} \mathrm{cfu} \mathrm{g}^{-1}$ of soil in the tidal-swamp

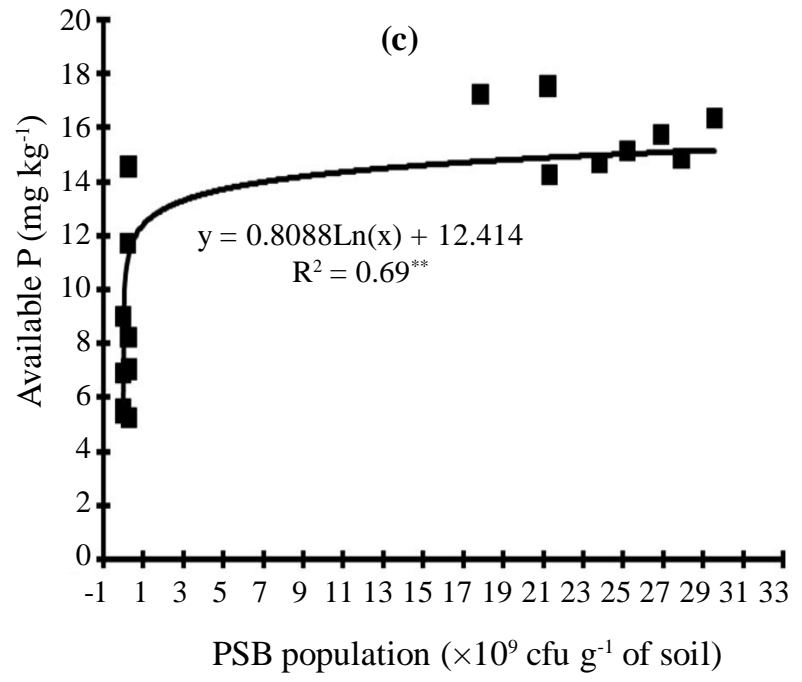

Figure 4. Relationship between available $\mathrm{P}$ and population density of PSB in Ultisols (a), fresh-water lowland Inceptisols (b), and tidal-swamp Inceptisols (c).

Inceptisols. Although it has been widely known that biological solubilization of fixed $\mathrm{P}$ in soil is through soil acidification, current experiment revealed that such mechanisms was not occurring. Instead of decreasing, the $\mathrm{pH}$ of soils used in current experiment increased with time, from $\mathrm{pH}$ of 5.03 
in the Ultisols, 4.78 in the fresh-water Inceptisol, and 4.04 in the tidal-swamp Inceptisols at the start of the experiment to ph of 5.61 in the Ultisols, 5.17 in the fresh-water Inceptisols, and 4.48 in the tidalswamp Inceptisol at the end of the experiment. A similar finding has also been reported earlier that inoculating soils with PSB did not necessarily resulted in any increases of organic acids and decreases of soil $\mathrm{pH}$ in spite of the increases in available $\mathrm{P}$ in soils (Asea et al. 1988; Illmer and Schiner 1995; Altomare et al. 1999). Therefore, it is concluded that the increases in the available $\mathrm{P}$ observed in current study were resulted in by chelation of both $\mathrm{Al}$ and $\mathrm{Fe}$, as shown by the significant decreases of $\mathrm{Al}-$ and $\mathrm{Fe}-\mathrm{P}$ omplexes in Figure 2 (He et al. 1990; Violante et al. 1991; He et al. 1992; Altomare et al. 1999; He et al. 2002).

\section{CONCLUSION}

Based on the results obtained it can be concluded that the availability of $\mathrm{P}$ in soils of current experiment was significantly correlated with the population size of PSB. The PSB population size determined the availability of $\mathrm{P}$ in Ultsiols, freshwater lowland Inceptisols, and tidal-swamp Inceptisol as much as 60\%, 55\%, and 69\%, consecutively. To obtain significant correction of the available $\mathrm{P}$ in the Ultisols, fresh-water lowland Inceptisols, and tidal-swamp Inceptisols, the population of PSB must be at least $0.53 \times 10^{9} \mathrm{cfu}^{-}$ ${ }^{1}$ of soil, $2.94 \times 10^{10} \mathrm{cfu} \mathrm{g}^{-1}$ of soil, and $1.73 \times 10^{10}$ $\mathrm{cfu}^{-1}$ of soil, cosecutively.

\section{ACKNOWLEDGEMENT}

This study was financially supported by Grant from PHK A2, Directorate General of Higher Education, Department of Education of Indonesia. Technical support from the Department of Soil Science, Faculty of Agriculture, Sriwijaya University and Post Graduate Study, Sriwijaya University is also highly acknowledged. We also thank the anonymous referees for their useful comments on this manuscript.

\section{REFERENCES}

Altomare C, WA Norvell, T Björkman and GE Harman. 1999. Solubilization of phosphates and micronutrients by the plant-growth-promoting and biocontrol fungus Trichoderna harziarum Rifai 1295-22. Appl Environ Microbiol 65: 2926-2933.

Asea PEA, RMN Kucey and JWB Stewart. 1988. Inorganic phosphate solubilization by two
Penicillium species insolution culture and soil. Biol and Biochem 20: 459-464.

Berry DF and C Hagedorn. 1991. Soil and groundwater transport of microorganisms. In: LR Ginsburg (ed). Assessing ecological risks of biotechnology. Butterworth-Heinemann, Stoneham, Mass, pp. 5773.

Bertrand I, RE Holloway, RD Armstrong and MJ McLaughlin. 2003. Chemical characteristics of phosphorus in alkaline soils from southern Australia. Austr J Soil Res 41: 61-76.

Bieleski RL. 1973. Phosphate pools, phosphate transport, and phosphate availability. Ann Rev Plant Physiol 24: 225-252.

Borling K, E Otabbong and E Barberis. 2001. Phosphorus sorption in relation to soil properties in some cultivated Swedish soils. Nutr Cycl Agroecosyst 59: 39-46.

Burt R, MD Mays, EC Benham and MA Wilson. 2002. Phosphorus characterization and correlation with properties of selected benchmark soils of the United States. Commun Soil Sci Plant Anal 33: 117-141.

Cerezine PC, E Nahas and DA Banzatto. 1988. Soluble phosphate accumulation by Aspergillus niger from flourapatite. Appl Microb Biotech 29: 501-505.

Daly K, D Jeffrey and H Tunney. 2001. The effect of soil type on phosphorus sorption capacity and desorption dynamics in Irish grassland soils. Soil Use Manag 17: 12-20.

Danso SKA and M Alexander. 1975. Regulation of predation by prey density: the protozoan-Rhizobium relationship. Appl Microbiol 29: 515-521.

Egamberdiyeva D, D Juraeva, S Poberejskaya, O Myachina, P Teryuhova, L Seydalieva and A Aliev. 2004. Improvement of wheat and cotton growth and nutrient uptake by phosphate solubilizing bacteria. http://www.ag.aurburn.edu/aux/nsdl/ sctcsa/Proceedings/2004/Egamberdiyeva.pdf. (accessed on 19 January, 2006).

Elliott ET, RV Anderson, DC Coleman and CV Cole. 1980. Habitable pore space and microbial trophic interaction. Oikos 35: 327-335.

Glick BR. 1995. The enhancement of plant growth by freeliving bacteria. Can J Microbiol 41: 109-117.

Goldstein AH. 1986. Bacterial phosphate solubilization: Historical perspective and future prospects. Am J Altern Agric 1: 57-65.

Gupta R, R Singal, R Sankar, RM Chander and RS Kumar. 1994. A modified plate essay for screening phosphate solubilizing microorganisms. J Appl Microbiol 40: 255-260.

Gyaneshwar P, G Naresh Kumar and LJ Parekh. 1998. Effect of buffering on the phosphate solubilizing ability of microorganisms. World J Microbiol Biotech 14: 669-673.

Habte M and M Alexander. 1975. Protozoa as agents responsible for the decline of Xanthomonas campestris in soil. Appl Microbiol 29: 159-164.

He ZI, KN Yuan and ZX Zhu. . 1992. Effect of organic ligands on phosphate desrption. Pedosphere 2: 1-11. 
He ZI, KN Yuan and ZX Zhu. 1990. Effect of organic ligands on phosphate adsorption by hydrous iron and aluminum oxides, kaolinite and red earth. Acta Pedol Sin 27: 377-384.

He ZI, W Bian and J Zhu. 2002. Screening and identification of microogrnisms capable of utilizing phosphate adsorbed by goethite. Comm Soil Sci Plant Anal 33: 647-663.

Heijnen CE, JD van Elsas, PJ Kuikman and JA van Veen. 1988. Dynamics of Rhizobium leguminosarum biovar trifolii introduced in soil: the effect of bentonite clay on predation by protozoa. Soil Biol Biochem 20: 483-488.

Ho WC and WH Ko. 1985. Soil microbiostatis: Effects of environmental and edaphic factors. Soil Biol Biochem 17: 167-170.

Holford ICR. 1997. Soil phosphorus: its measurement, and its uptake by plants. Aust J Soil Res 35: 227239.

Ige DV, JA Adepetu, OA Obi and MT Adetunji. 2003. Phosphate sorption potential as a predictor of plant available phosphate in soils of southwestern Nigeria. African Soils 33: 13-27.

Igual JM, AValverde, E Cervantes and E Velásquez. 2001. Phosphate-solubilizing bacteria as inoculants for agriculture: use of updated molecular techniques in their study. Agronomie 21: 561-568.

Illmer $P$ and F Schiner. 1995. Solubilization of inorganic calcium phosphate: Solubilization mechanism. Soil Biol Biochem 27: 257-264.

Illmer P, A Barbato and F Schiner. 1995. Solubilization of hardly-soluble $\mathrm{AlPO}_{4}$ with P-solubilizing microorganisms. Soil Biol Biochem 27: 265-270.

Jeffries P and JM Barea. 1994. Biogeochemical cycling and arbuscular mycorrhizas in the sustainability of plant-soil systems. In: S Gianinazzi and H Schue (eds). Impact of arbuscular mycorrhizas on sustainable agriculture and natural ecosystems. Birkhäuser Verlag, Basel, Switzerland, pp. 101115.

Leclerc ML, MC Nolin, D Cluis and RR Simard. 2001. Grouping soils of the Montreal Lowlands (Quebec) according to fertility and $\mathrm{P}$ sorption and desorption characteristics. Can J Soil Sci 81: 71-83.

Marshall K. 1975. Clay mineralogy in relation to survival of soil bacteria. Ann Rev Phytopathol 13: 357-373.

Marsi and Sabaruddin. 2006. Fixation capacity and rate of solubilization of $\mathrm{P}$ in acid Ultisols, fresh-water tidal Inceptisols, and tidal-swamp Inceptisols. Research Report financially supported by Grant from PHK A2, Directorate General of Higher Education, Department of Education of Indonesia (No. K.003.170/KPMPT/A2/II-1/2005 March 28, 2005). Faculty of Agriculture, Sriwijaya University, Indonesia.

Mehadi A and RW Taylor. 1988. Phosphate adsorption by two highly weathered soils. Soil Sci Soc Am J 52: 627-632.
Oberson A, JC Fardeau, JM Besson and H Sticher. 1993. Soil phos-phorus dynamics in cropping systems managed according to conventional and biological agricultural methods. Biol Fert Soils 16: 111-189.

Paul EA and FE Clark. 1989. Soil microbiology and biochemistry. Academic Press Inc., New york.

Postma J, CH Hok, A Hin and JA van Veen. 1990. Role of microniches in protecting introduced Rhizobium leguminosarum biovar trifolii against competition and predation in soil. J Microbiol 56: 495-502.

Rajan SSS and JH Watkinson. 1976. Adsorption of selenite and phosphate on an allopahne clay. Soil Sci Soc Am J 40: 51-54.

Reyes I, L Bernier and H Antoun. 2002. Rock phosphate solubilization and colonization of maize rhizosphere by wild and genetically modified strains of Penicillium rugulosum. Microb Ecol 44: 39-48.

Rodríguez H and R Fraga. 1999. Phosphate solubilizing bacteria and their role in plant growth promotion. Biotechnol Adv 17: 319-339.

Sabarudin. 2004. Indigenous P-solubilizing response on liming following fire on Acacia mangium plantation. J. Trop Soils 10(1): 55-62.

Subba Rao NS. 1993. Biofertilizers in Agriculture and Forestry. Oxford and IBH Publishing Co. Pvt. Ltd., New Delhi.

Taiwo LB and M Ogundiya. 2008. Microbial solubilization of Ogun rock phosphate in the laboratory and in soil. African J Microbiol Res 2: 308-312.

van Elsas JD, CE Heijnen and JA van Veen. 1991. The fate of introduced genetically engineered microorganisms in soil, in microcosms and the ûeld: impact of soil textural spects. In: DR MacKenzie and SC Henry (eds). Biological monitoring of genetically engineered plants and microbes'. Agricultural Research Institute, Bethesda, Md, pp. 67-79.

van Elsas, JD, AF Dijkstra, JM Govaert and JA van Veen. 1986. Survival of Pseudomonas fluorescens and Bacillus subtilis introduced into two soils of different texture in field microplots. FEMS Microbiol Ecol 38: 151-160.

van Veen JA, LS van Overbeek and JD van Elsas. 1997. Fate and activity of introduced microorganisms introduce into soil. Microbiol Mol Biol Rev 61(2): 121-135.

Violantem A, C Colombo and A Buondonno. 1991. Competitive adsorption of phosphate and oxalate by aluminum oxide. Soil Sci Soc Am J 55: 65-70.

Wright DA, K Killham, LA Glover and JI Prosser. 1993. The effect of location in soil on protozoal grazing of a genetically modiûed bacterial inoculum. Geoderma 56: 633-640.

Wright DA, K Killham, LA Glover and JI Prosser. 1995. Role of pore size location in determining bacterial activity during predation by protozoa in soil. Appl Environ Microbiol 61: 3537-3543.

Zhang H, JL Schroder, JK Fuhrman, NT Basta, DE Storm and ME Payton. 2005. Path and multiple regression analyses of phosphorus sorption capacity. Soil Sci Soc Am J 69: 96-106. 